\title{
TINDAK PIDANA TURUT SERTA SEBAGAI PERANTARA SUAP PERSPEKTIF HUKUM PIDANA ISLAM
}

\author{
Adeng Septi Irawan $\mid \begin{aligned} & \text { Tribun Jatim, Dinoyo Alun-alun IV/10 } \\ & \text { Keputran Surabaya }\end{aligned}$ \\ irawan_34@yahoo.com Keputran Surabaya
}

Abstract: This article discusses about the sanction of criminal act as a bribery mediator under the perspective of Islamic Criminal Law. The criminal act as a bribery mediator is explained in the Penal Code in Article 55 Paragraph (1) ie those who do, who order to do, and who participate in doing the deed. The bribery crime is also described in Article 12 SubArticle c of Law No. 31 year 1999 jo Law No. 20 year 2001 on the "eradication of corruption cases that punishment for the perpetrator of bribery, gratification, etc., will be imprisoned and/or sanction. Even in the specific provision, if corruption is done by causing harm to the state, such as a national disaster or at a time when the country is in a state of economic crisis, it can be subject to capital punishment. The purposes of applying punishment in positive law are to create certainty, justice, and legal benefit in Indonesia. The Islamic criminal law has made it clear that unlawful acts in bribery (isytirâk fi al jarîmah al-risywah) according to Muslim scholars are haram (unlawful). The punishment for the perpetrators of isytirâk fî al jarîmah al-risywah is ta'zîr.

Keywords: Criminal act, bribery mediator, Islamic criminal law.

Abstrak: Artikel ini membahas tentang sanksi tindak pidana turut serta sebagai perantara suap perspektif hukum pidana Islam. Tindak pidana turut serta dijelaskan dalam KUHP dalam pasal 55 ayat (1) yaitu mereka yang melakukan, yang menyuruh melakukan, dan yang turut serta melakukan perbuatan. Adapun tindak pidana suap dijelaskan dalam Pasal 12 huruf c UU Nomor 31 Tahun 1999 jo UU Nomor 20 Tahun 2001 tentang Pemberantasan Tindak Pidana Korupsi bahwa ancaman hukuman bagi pelakunya, baik itu suap, gratifikasi, dan lain-lain, akan dikenakan hukuman penjara dan/atau denda. Bahkan dalam ketentuan khususnya, apabila korupsi dilakukan dengan mengakibatkan bahaya bagi negara, seperti terjadi bencana nasional atau pada saat negara dalam keadaan krisis ekonomi, maka dapat diancam hukuman mati. Tujuan penerapan hukuman tersebut adalah menciptakan kepastian, keadilan, dan kemanfaatan hukum di Indonesia. Hukum pidana Islam telah menjelaskan bahwa perbuatan melawan hukum dalam turut serta suap (isytirâk fî jarîmah al-risywah) menurut para ulama adalah haram dan hukumannya adalah ta'zîr.

Kata Kunci: Tindak pidana, perantara suap, hukum pidana Islam. 


\section{Pendahuluan}

Kondisi aparat penegak hukum saat ini sungguh sangat memprihatinkan. Berita kejahatan dan pelanggaran yang dilakukan oleh para penegak hukum seringkali muncul. Penegak hukum terdiri dari polisi, jaksa, hakim, dan advokat. Hukum seolah-olah menjadi suatu alat untuk mewujudkan keinginan masing-masing individu. Hukum yang sejatinya difungsikan untuk mengatur dan mengendalikan masyarakat malah menjadi sarana bagi penegak hukum untuk mencari keuntungan materiil.

Nilai keadilan yang termuat dalam Pancasila sila kelima seolah hanya menjadi simbol saja, tanpa ada makna yang terkandung di dalamnya. Ketidak seimbangan antara kenyataan dan harapan menjadi suatu hal yang terus menjadi permasalahan di kalangan para penegak hukum. Pada dasarnya, suatu peraturan perundang-undangan dibuat oleh pemerintah sebagai pembatas bagi masyarakat agar tidak melampaui batas dalam berbuat. Penegak hukum selaku orang yang paham mengenai hukum harusnya menjadi teladan bagi masyarakat, bukan malah melakukan pelanggaran terhadap hukum. Negara hukum merupakan bentuk dari negara Indonesia sesuai yang tercantum dalam Undang Undang Dasar 1945. ${ }^{1}$

Penegakan hukum merupakan salah satu usaha untuk menciptakan tata tertib, keamanan, dan ketentraman dalam masyarakat, baik itu merupakan usaha pencegahan maupun pemberantasan atau penindakan setelah terjadinya pelanggaran hukum, dengan kata lain secara represif maupun preventif. ${ }^{2}$

Asas legalitas yang diatur dalam pasal 1 ayat (1) KUHP yang berbunyi: "Tiada suatu perbuatan yang boleh dihukum melainkan atas kekuatan ketentuan pidana dalam undang undang yang ada terlebih dahulu dari perbuatan itu". ${ }^{3}$ Jelas bahwa perbuatan yang tidak diatur dalam undang-undang tidak dapat dipidanakan.

Indonesia menganut unsur dualistis dalam penerapan hukum pidana yaitu unsur perbuatan dan pertanggungjawaban. Keduanya

\footnotetext{
${ }^{1}$ Sekretariat Jenderal MPR RI, Undang-Undang Dasar 1945 dalam Satu Naskah, Jakarta: Sekjen MPR RI, 2013), 116.

${ }^{2}$ Moch. Faizal Salam, Hukum Acara Pidana dalam Teori dan Praktek, (Bandung:Mandar Maju, 2001), 1.

${ }^{3}$ Tim Grahamedia Press, KUHP \& KUHAP, (Surabaya: Grahamedia Press, 2012), 3.
} 
memiliki implikasi yang berlainan satu sama lain. ${ }^{4}$ Kesalahan dalam arti seluas-luasnya dapat disamakan dengan pengertian "pertanggungjawaban dalam hukum pidana", di dalamnya terkandung makna "dapat dicelanya si pembuat atas perbuatannya". Jadi, apabila dikatakan seseorang bersalah melakukan sesuatu tindak pidana, maka itu berarti dia dapat dicela atas perbuatannya. Kesalahan dalam arti bentuk-bentuk kesalahan dapat juga dikatakan kesalahan dalam arti yuridis, yang berupa: kesengajaan (dolus atau intention) dan kealpaan (culpa atau negligence). ${ }^{5}$ Dengan diterimanya pengertian kesalahan (dalam arti luas) sebagai dapat dicelanya si pembuat atas perbuatannya, maka berubahlah pengertian kesalahan yang psikologis menjadi pengertian kesalahan yang normatif. Pengertian kesalahan yang psikologis yaitu kesalahan hanya dipandang sebagai hubungan batin antara pembuat dan perbuatannya. Hubungan batin tersebut bisa berupa kesengajaan atau kealpaan. Pada kesengajaan hubungan batin itu berupa menghendaki perbuatan (beserta akibatnya) sedangkan pada kealpaan tidak ada kehendak demikian.

Korupsi berasal dari bahasa Latin "corruptio" (penyuapan), "corruptore" (merusak). Korupsi yaitu perbuatan yang buruk seperti penggelapan uang, penerimaan uang sogok, dan sebagainya. Dengan demikian, secara harfiah dapat diketahui bahwa sesungguhnya istilah korupsi memiliki arti yang luas, di antaranya: korupsi berupa penyelewengan atau penggelapan (uang negara atau perusahaan, dan sebagainya) untuk kepentingan pribadi dan orang lain; Korupsi berupa suka memakai barang atau uang yang dipercayakan kepadanya, dapat disuap (melalui kekuasaannya untuk kepentingan pribadi). ${ }^{6}$

UU Nomor 31 Tahun 1999 tentang Pemberantasan Tindak Pidana Korupsi sebagaimana telah diubah dengan UU Nomor 20 Tahun 2001 tentang Pemberantasan Tindak Pidana Korupsi memuat pengertian korupsi yaitu; setiap orang yang memberi atau menjanjikan sesuatu kepada hakim dengan maksud untuk mempengaruhi putusan perkara yang diserahkan kepadanya untuk diadili, atau memberi, atau menjanjikan sesuatu kepada seseorang yang menurut peraturan perundang undangan ditentukan menjadi advokat untuk menghadiri sidang pengadilan dengan maksud untuk mempengaruhi nasihat atau pendapat yang akan diberikan

\footnotetext{
${ }^{4}$ Amir llyas, Asas-Asas Hukum Pidana, (Yogyakarta: Mahakarya Rangkang Offset, 2012), 40.

${ }^{5}$ Azis Syamsuddin, Tindak Pidana Khusus, (Jakarta: Sinar Grafika, 2011), 151.

${ }^{6}$ Evi Hartanti, Tindak Pidana Korupsi, (Jakarta: Sinar Grafika, 2012), 9.
} 
berhubungan dengan perkara yang diserahkan kepada pengadilan untuk diadili. $^{7}$

UU Nomor 31 Tahun 1999 jo UU Nomor 20 Tahun 2001 mengalami perluasan perumusan delik (tindak pidana). Perluasan tersebut pada rumusan dalam penafsiran arti melawan hukum. UU Nomor 31 Tahun 1999 jo UU Nomor 20 Tahun 2001 menyatakan bahwa tindak pidana korupsi sebagai delik formal, namun pengertian melawan hukum dalam tipikor sebagai delik formal dan material.

Sebagai delik formal, suatu perbuatan dapat dinyatakan sebagai tindak pidana jika perbuatan tersebut telah memenuhi rumusan delik dalam undang-undang tanpa harus menimbulkan akibat yang merugikan. Jadi, meskipun perbuatan itu belum sampai menimbulkan kerugian keuangan negara, tetapi jika perbuatan itu telah dapat dikategorikan akan menimbulkan kerugian negara, pelakunya sudah dapat dihukum. Begitu pun halnya dalam hal hasil tindak pidana korupsi yang telah dikembalikan kepada negara, akan tetapi tidak dapat menghapus sifat melawan hukum perbuatan tersebut. Sementara, pengertian sifat melawan hukum formal dan material menunjuk pada suatu perbuatan, tidak hanya bertentangan dengan peraturan perundang undangan yang berlaku, tetapi juga merupakan perbuatan tercela dan bertentangan dengan perasaan keadilan masyarakat. Sifat melawan hukum formal dan material terkandung dalam UU Nomor 31 Tahun 1999 jo UU Nomor 20 Tahun 2001, sebagaimana dirumuskan dalam penjelasan umum "Suatu perbuatan dikatakan melawan hukum, dalam pengertian formil dan materiil, bilamana tindak pidana korupsi tersebut mencakup perbuatan-perbuatan tercela yang menurut perasaan keadilan masyarakat harus dituntut dan dipidana".

Turut serta dalam pasal 55 ayat (1) kesatu KUHP, maksudnya yaitu mereka yang melakukan, yang menyuruh melakukan, dan yang turut serta melakukan perbuatan. ${ }^{8}$ Contoh kasus turut serta dalam tindak pidana suap adalah kasus advokat Susi Tur Andayani yang menjadi perantara suap terhadap Akil Mochtar Lubis (hakim konstitusi) dalam sengketa pilkada Lebak dan Lampung Selatan. Hal tersebut menjadi hal yang menodai citra penegakan hukum di Indonesia.

\footnotetext{
7 Pasal 6 ayat (1) huruf a dan b UU No. 31 Tahun 1999 jo UU No. 20 Tahun 2001 tentang Pemberantasan Tindak Pidana Korupsi.

${ }^{8}$ Tim Grahamedia Press, KUHP \& KUHAP, 20.
} 
Mengacu pada hal tersebut, Islam sepenuhnya melarang orang yang melakukan suap dan orang yang menerima suap. Terlebih lagi dalam dunia hukum berkaitan dengan proses suap-menyuap untuk mempengaruhi putusan hakim. Sehingga sejak awal keberadaannya, Islam telah mengatur tentang sanksi bagi aparat penegak hukum yang melakukan dan menerima suap. Sehingga hal ini diharapkan mampu menciptakan keadilan, kepastian dan kemanfaatan hukum di Indonesia. Dalil yang menunjukkan dilarangnya perbuatan suap-menyuap dan yang sejenisnya berdasarkan QS. al-Maidah (42):

"Mereka itu adalah orang-orang yang suka mendengar berita bohong, banyak memakan yang haram. Jika mereka (orang Yahudi) datang kepadamu (untuk meminta putusan), maka putuskanlah (perkara itu) di antara mereka, atau berpalinglah dari mereka; jika kamu berpaling dari mereka, maka mereka tidak akan memberi mudharat kepadamu sedikitpun. Dan jika kamu memutuskan perkara mereka, maka putuskanlah (perkara itu) di antara mereka dengan adil, sesungguhnya Allah menyukai orang-orang yang adil."

Ibn Taimiyah berkata bahwa yang dimaksud dengan akkâlûna li assuht adalah memakan hasil suap. ${ }^{10}$ Hadis Nabi Muhammad saw yang melarang suap menyuap dan sejenisnya adalah ${ }^{11}$

Dari Abu Hurairah ra, ia berkata; Rasulullah saw melaknati penyuap dan yang disuap dalam masalah hukum. ${ }^{12}$

Secara implisit, ayat dan hadis di atas mengandung perintah untuk menghindari perbuatan suap menyuap dan sejenisnya, karena perbuatan suap menyuap sangatlah dilarang oleh Allah swt. Sebagai aparat penegak hukum, tentunya harus menghindari praktik suap menyuap tersebut. Di antara manusia terdapat hukum-hukum dan hak-hak yang harus ditegakkan. ${ }^{13}$ Penegakan hukum yang dimaksud adalah penegakan hukum pidana, yang terdiri dari dua macam; Pertama, hukum pidana yang merupakan hak Allah, dan yang kedua, hukum pidana yang merupakan hak manusia. ${ }^{14}$

\footnotetext{
${ }^{9}$ Departemen Agama, Al-Qur'an dan Terjemahnya, (Surabaya: CV. Karya Utama, 2000), 152.

${ }^{10}$ A. Djazuli, Fiqh Jinayah, (Jakarta: Raja Grafindo Persada, 2000), 187.

${ }^{11}$ HR. Sunan At-Tirmidzi Hadis no. 1256 (Lidwa Pustaka i Software)

${ }^{12}$ Ibid. Hadis No. 1256.

${ }^{13}$ Ibnu Taimiyah, Siyasah Syar'iyah; Etika Politik Islam, terj. Rofi' Munawar, (Surabaya: Risalah Gusti, 1999), 61.

${ }^{14}$ Munawir Sjadzali, Islam dan Tata Negara, (Jakarta: Universitas Indonesia, 1993), 87.
} 
Penegakan hukum pidana sangat penting sebagai amanat Allah swt. Selain itu terdapat tujuan dalam hukum pidana Islam, di antaranya: menjamin keamanan lima pokok kebutuhan hidup yang primer (dharûriyyât), atau disebut dengan istilah al-maqâshid al-khamsah, meliputi: agama, jiwa, akal dan pikiran, keturunan, dan hak milik. Selanjutnya kebutuhan sekunder atau disebut (hâjiyyât), dan yang terakhir adalah kebutuhan tersier (tahsîniyyât), yaitu menjadikan hal-hal yang dapat menghiasi kehidupan sosial dan menjadikan manusia mampu berbuat dan mengatur urusan hidup lebih baik. ${ }^{15}$ Pertimbangan dicantumkannya pengertian formal dan material dalam UU Nomor 31 Tahun 1999 jo UU Nomor 20 Tahun 2001, di antaranya yaitu: mengingat tindak pidana korupsi terjadi secara sistematis dan meluas tidak hanya merugikan keuangan dan perkonomian negara tetapi merupakan pelanggaran terhadap hak-hak sosial dan ekonomi masyarakat secara luas (digolongkan sebagai extra ordinary crime) sehingga pemberantasannya harus dilakukan dengan cara yang luar biasa; mengingat dampak dari Tipikor selama ini, selain merugikan keuangan negara juga menghambat pertumbuhan dan kelangsungan pembangunan nasional yang menuntut efisiensi tinggi; dan untuk merespon perkembangan kebutuhan hukum dalam masyarakat, agar lebih memudahkan di dalam pembuktian sehingga dapat menjangkau berbagai modus operandi penyimpangan keuangan atau perekonomian negara yang semakin canggih dan rumit. Berdasarkan hal tersebut, maka artikel ini membahas tentang sanksi tindak pidana turut serta sebagai perantara suap perspektif hukum pidana Islam.

\section{Tindak Pidana Suap Menurut Undang-undang}

Tindak Pidana atau strafbaarfeit atau perbuatan pidana merupakan suatu perbuatan yang dilarang oleh suatu aturan hukum, larangan di mana disertai ancaman (sanksi) yang berupa pidana tertentu, barangsiapa melanggar larangan tersebut. ${ }^{16}$

Definisi arti kata suap (bribery) bermula dari asal kata briberie (Perancis) yang artinya adalah begging (mengemis) atau vagrancy (penggelandangan). Dalam bahasa Latin disebut briba, yang artinya a piece of bread given to beggar (sepotong roti yang diberikan kepada pengemis). Dalam perkembangannya bribe bermakna sedekah (alms), blackmail, atau extortion (pemerasan) dalam kaitannya dengan gifts

${ }^{15}$ Topo Santoso, Membumikan Hukum Pidana Islam, (Jakarta: Gema Insani Press, 2003), 19.

${ }^{16}$ Adami Chazawi, Pelajaran Hukum Pidana Bagian I, (Jakarta: Raja Grafindo Persada, 2002$), 71$. 
received or given in order to influence corruptly (pemberian atau hadiah yang diterima atau diberikan dengan maksud untuk memengaruhi secara jahat atau korup).

Pengertian suap adalah suatu tindakan dengan memberikan sejumlah uang atau barang atau perjanjian khusus kepada seseorang yang mempunyai otoritas atau yang dipercaya, contoh para pejabat, dan membujuknya untuk mengubah otoritasnya demi keuntungan orang yang memberikan uang atau barang atau perjanjian lainnya sebagai kompensasi sesuatu yang dia inginkan untuk menutupi tuntutan lainnya yang masih kurang.

Buku "Memahami untuk Membasmi" yang dikeluarkan Komisi Pemberantasan Korupsi (KPK) telah menjelaskan secara jelas dan lengkap tentang pasal-pasal yang digolongkan ke dalam suap-menyuap beserta unsur-unsurnya dalam UU Nomor 31 Tahun 1999 jo UU Nomor 20 Tahun 2001 tentang Pemberantasan Tindak Pidana Korupsi, di antaranya: ${ }^{17}$

a. Pasal 5 ayat (1) huruf a (Menyuap Pegawai Negeri adalah Korupsi)

b. Pasal 5 ayat (1) huruf b (Menyuap Pegawai Negeri adalah Korupsi)

c. Pasal 13 (Memberi hadiah kepada Pegawai Negeri karena Jabatannya adalah korupsi)

d. Pasal 5 ayat 2 (Pegawai negeri menerima suap adalah korupsi)

e. Pasal 12 huruf a (Pegawai Negeri menerima suap adalah korupsi)

f. Pasal 12 huruf b (Pegawai Negeri menerima suap adalah korupsi)

g. Pasal 11 (Pegawai negeri menerima hadiah yang berhubungan dengan jabatannya adalah korupsi)

h. Pasal 6 ayat (1) huruf a (Menyuap hakim adalah korupsi)

i. Pasal 6 ayat (1) huruf b (Menyuap advokat adalah korupsi)

j. Pasal 6 ayat (2) (Hakim dan advokat menerima suap adalah korupsi)

k. Pasal 12 huruf c (Hakim menerima suap adalah korupsi)

1. Pasal 12 huruf $d$ (Advokat menerima suap adalah korupsi)

Unsur-Unsur Suap, yaitu:

a. Setiap orang,

b. Memberi sesuatu,

c. Kepada pegawai negeri atau penyelenggara negara,

${ }_{17}$ UU Nomor 31 Tahun 1999 jo UU Nomor 20 Tahun 2001 tentang Pemberantasan Tindak Pidana Korupsi. 
d. Karena atau berhubungan dengan sesuatu yang bertentangan dengan kewajiban, dilakukan atau tidak dilakukan dalam jabatannya. ${ }^{18}$

\section{Penyertaan (deelneming) dalam Tindak Pidana Suap}

Penyertaan (deelneming) dalam hukum positif yaitu ada dua orang atau lebih yang melakukan suatu tindak pidana atau dengan perkataan ada dua orang atau lebih mengambil bagian untuk mewujudkan suatu tindak pidana dapat disebutkan bahwa seseorang tersebut turut serta dalam hubungannya dengan orang lain (diatur dalam pasal 55 dan 56 KUHP). ${ }^{19}$

Prof. Satochid Kartanegara mengartikan deelneming apabila dalam satu delik tersangkut beberapa orang atau lebih dari satu orang. Menurut doktrin, deelneming berdasarkan sifatnya terdiri atas: ${ }^{20}$

a. Deelneming yang berdiri sendiri, yakni pertanggung jawaban dari setiap peserta dihargai sendiri-sendiri.

b. Deelneming yang tidak berdiri sendiri, yakni pertanggungjawaban dari peserta yang satu digantunggkan dari perbuatan peserta yang lain.

Penyertaan dalam hukum pidana, diatur dalam Pasal 55 dan 56 KUH Pidana: ${ }^{21}$

a. Unsur-unsur para pembuat (Mededader) dalam pasal 55 KUHP, antara lain:

(1) Pleger (orang yang melakukan)

Seseorang yang termasuk golongan ini adalah pelaku tindak pidana yang melakukan perbuatannya sendiri, baik dengan memakai alat maupun tidak memakai alat. Dengan kata lain, pleger adalah seseorang yang memenuhi seluruh unsur yang ada dalam suatu perumusan karakteristik delik pidana dalam setiap pasal.

(2) Doen Plegen (orang yang menyuruh melakukan)

Perbuatan dapat dikategorikan sebagai doen plegen, paling sedikit harus ada dua orang, di mana salah seorang bertindak sebagai perantara. Sebab doen plegen adalah seseorang yang ingin melakukan tindak pidana, tetapi dia tidak melakukannya sendiri melainkan menggunakan atau menyuruh orang lain, dengan catatan yang dipakai atau disuruh tidak bisa menolak atau menentang kehendak orang yang

\footnotetext{
18 Komisi Pemberantasan Korupsi, Memahami untuk Membasmi (Buku Saku untuk Memahami Tindak Pidana Korupsi), (Jakarta: KPK, 2006), 17.

${ }^{19}$ Erdianto Effendi, Hukum Pidana Indonesia, (Bandung: Refika Aditama, 2011), 174.

${ }^{20}$ Satochid Kartanegara, Hukum Pidana Kumpulan Kuliah bagian satu, (Balai Lektur Mahasiswa), 497 $-498$.

${ }^{21}$ Tim Grahamedia Press, KUHP \& KUHAP, 20.
} 
menyuruh melakukan. Dalam posisi yang demikian, orang yang disuruh melakukan itu harus pula hanya sekedar menjadi alat (instrumen) belaka, dan perbuatan itu sepenuhnya dikendalikan oleh orang yang menyuruh melakukan. Sesungguhnya yang benar-benar melakukan tindak pidana langsung adalah orang yang disuruh melakukan, tetapi yang bertanggung jawab adalah orang lain, yaitu orang yang menyuruh melakukan. Hal ini disebabkan orang yang disuruh melakukan secara hukum tidak bisa dipersalahkan atau tidak dapat dipertanggungjawabkan. Orang yang disuruh mempunyai dasardasar yang menghilangkan sifat pidana. Sebagaimana diatur dalam Pasal 44, Pasal 48, Pasal 49, Pasal 50 dan Pasal 51 KUH Pidana.

(3) Medepleger (orang yang turut melakukan)

Perbuatan dapat dikategorikan sebagai medepleger, paling sedikit juga harus tersangkut dua orang, yaitu orang yang menyuruh melakukan (pleger) dan orang yang turut melakukan (medepleger). Disebut turut melakukan, karena ia terlibat secara langsung bersama pelaku dalam melakukan suatu tindak pidana, dan bukan hanya sekedar membantu atau terlibat ketika dalam tindakan persiapan saja. Ini berarti antara orang yang turut melakukan dengan pelaku, harus ada kerjasama secara sadar dan sengaja.

(4) Uitlokker (orang yang membujuk melakukan)

Secara sederhana pengertian uitlokker adalah setiap orang yang menggerakkan atau membujuk orang lain untuk melakukan suatu tindak pidana. Istilah menggerakkan atau membujuk ruang lingkup pengertiannya sudah dibatasi oleh Pasal 55 ayat (1) bagian $1 \mathrm{KUH}$ Pidana yaitu dengan cara memberikan atau menjanjikan sesuatu, menyalahgunakan kekuasaan atau martabat, dengan kekerasan, ancaman atau penyesatan, memberi kesempatan, sarana dan keterangan. Berbeda dengan orang yang disuruh melakukan, orang yang dibujuk tetap dapat dihukum, karena dia masih tetap mempunyai kesempatan untuk menghindari perbuatan yang dibujukkan kepadanya. Tanggung jawab orang yang membujuk (uitlokker) hanya terbatas pada tindakan dan akibat-akibat dari perbuatan yang dibujuknya, selebihnya tanggung jawab yang dibujuk sendiri.

b. Unsur-unsur Pembuat Pembantu (Medeplichtigheid) dalam pasal 56 KUHP, antara lain: 
(1) Seseorang yang sengaja memberi bantuan pada waktu/saat kejahatan dilakukan

(2) Seseorang yang memberi kesempatan sarana atau keterangan untuk melakukan kejahatan (sebelum kejahatan dilakukan)

Semua golongan yang disebut Pasal 55 KUH Pidana dapat digolongkan sebagai pelaku tindak pidana, sehingga hukuman untuk mereka juga disamakan. Sebaliknya, Pasal 56 KUH Pidana mengatur mengenai orang digolongkan sebagai orang yang membantu melakukan tindak pidana (medeplichtig) atau pembantu. Orang dikatakan termasuk sebagai yang membantu tindak pidana jika ia memberikan bantuan kepada pelaku pada saat atau sebelum tindak pidana tersebut dilakukan. Apabila bantuan diberikan sesudah tindakan, tidak lagi termasuk orang yang membantu tetapi termasuk sebagai penadah atau persekongkolan. Sifat bantuan bisa berbentuk apa saja, baik materiil maupun moral. Tetapi antara bantuan yang diberikan dengan hasil bantuannya harus ada sebab akibat yang jelas dan berhubungan. Begitu pula sifat bantuan harus benarbenar dalam taraf membantu dan bukan merupakan suatu tindakan yang berdiri sendiri. Perbuatan yang sudah berdiri sendiri tidak lagi termasuk turut membantu tetapi sudah menjadi turut melakukan. Inisiatif atau niat harus pula datang dari pihak yang diberi bantuan, sebab jika inisiatif atau niat itu berasal dari orang yang memberi bantuan, sudah termasuk dalam golongan membujuk melakukan (uitlokker).

\section{Hukuman bagi Pelaku Tindak Pidana Suap}

Hukuman bagi pelaku korupsi dalam perundangan-undangan Indonesia telah diatur secara jelas dan lengkap, yakni dalam UndangUndang Nomor 31 Tahun 1999 jo Undang-Undang Nomor 20 Tahun 2001 tentang Pemberantasan Tindak Pidana Korupsi. Ancaman hukuman bagi pelakunya, baik itu suap, gratifikasi, dan lain-lain, akan dikenakan hukuman penjara dan/atau denda. Bahkan dalam ketentuan khususnya, apabila korupsi dilakukan dengan mengakibatkan bahaya bagi negara, seperti terjadi bencana nasional atau pada saat negara dalam keadaan krisis ekonomi, maka dapat diancam hukuman mati. Tujuan penerapan hukuman dalam hukum positif yaitu menciptakan kepastian, keadilan, dan kemanfaatan hukum di Indonesia.

Berdasarkan ketentuan Undang-Undang Nomor 31 Tahun 1999 jo Undang-Undang Nomor 20 Tahun 2001 tentang Pemberantasan Tindak Pidana Korupsi dan KUHP, jenis penjatuhan pidana yang dapat 
dilakukan hakim terhadap terdakwa tindak pidana suap dalam dunia peradilan adalah sebagai berikut:

a. Pidana Mati

Dapat dipidana mati kepada setiap orang yang secara melawan hukum melakukan perbuatan memperkaya diri sendiri atau orang lain atau suatu korporasi yang dapat merugikan keuangan negara atau perekonomian negara sebagaimana ditentukan dalam Pasal 2 ayat (1) Undang-undang Nomor 31 Tahun 1999 jo Undang-undang Nomor 20 Tahun 2001 tentang Pemberantasan Tindak Pidana Korupsi, yang dilakukan dalam keadaan tertentu.

b. Pidana Penjara

c. Pidana Kurungan

d. Pidana Denda

e. Pidana Tambahan

(1) Perampasan barang bergerak yang berwujud atau yang tidak berwujud atau barang tidak bergerak yang digunakan untuk atau yang diperoleh dari tindak pidana korupsi, termasuk perusahaan milik terpidana dimana tindak pidana korupsi dilakukan, begitu pula dari barang yang menggantikan barang-barang tersebut.

(2) Pembayaran uang pengganti yang jumlahnya sebanyak-banyaknya sama dengan harta yang diperoleh dari tindak pidana korupsi.

(3) Penutupan seluruh atau sebagian perusahaan untuk waktu paling lama 1 (satu) tahun.

(4) Pencabutan seluruh atau sebagian hak-hak tertentu atau penghapusan seluruh atau sebagian keuntungan tertentu yang telah atau dapat diberikan oleh pemerintah kepada terpidana.

(5) Jika terpidana tidak membayar uang pengganti paling lama dalam waktu 1 (satu) bulan sesudah putusan pengadilan yang telah memperoleh kekuatan hukum tetap maka harta bendanya dapat disita oleh jaksa dan dilelang untuk menutupi uang pengganti tersebut.

(6) Dalam hal terpidana tidak mempunyai harta benda yang mencukupi untuk membayar uang pengganti maka terpidana mengganti dengan pidana penjara yang lamanya tidak memenuhi ancaman maksimum dari pidana pokoknya sesuai ketentuan Undang-Undang Nomor 31 Tahun 1999 jo Undang-Undang Nomor 20 Tahun 2001 tentang Pemberantasan Tindak Pidana 
Korupsi dan lamanya pidana tersebut sudah ditentukan dalam putusan pengadilan.

\section{Tindak Pidana Suap (Jarîmah al-Risywah) menurut Hukum Pidana Islam}

Tindak Pidana (jarîmah), menurut bahasa, jarîmah berasal dari kata jarama, yang sinonimnya (kasaba wa qatha'a), artinya: berusaha dan bekerja. Hanya saja pengertian usaha ini khusus untuk usaha yang tidak baik atau usaha yang di benci oleh manusia. ${ }^{22}$

Menurut istilah, Imam al-Mawardi mengemukakan bahwa jarîmah adalah perbuatan-perbuatan yang dilarang oleh syara', yang diancam dengan hukuman had atau ta'zîr. ${ }^{23}$

Suap berarti risywah berasal dari bahasa Arab (rasyâ-yarsyû) yaitu upah, hadiah, komisi, atau suap. Secara terminologi, risywah adalah suatu pemberian yang diberikan seseorang kepada hakim, petugas atau pejabat tertentu dengan tujuan yang diinginkan kedua belah pihak, baik pemberi maupun penerima.

Sebagaimana disebutkan oleh Ali ibn Muhammad al-Jarjuni dalam kitab Ta'rîfât, suap adalah sesuatu yang diberikan untuk menyalahkan yang benar atau membenarkan yang salah.

Risywah adalah sesuatu yang diberikan setelah permintaan, sedangkan hadiah diberikan sebelumnya. Adapun hibah adalah pemberian tanpa ada ganti atau imbalan. Shadaqah adalah harta yang dikeluarkan seseorang dalam alasan untuk mendekatkan diri kepada Allah, seperti zakat. Perbedaan antara risywah, shadaqah, dan hadiah adalah terletak pada tujuannya. Risywah diberikan untuk mencapai suatu target duniawi untuk masa sekarang/secepatnya, shadaqah dikeluarkan dengan tujuan untuk mencari ridha Allah, sedangkan hadiah diberikan untuk memuliakan atau sebagai penghormatan kepada seseorang.

Pada intinya, risywah atau suap adalah suatu pemberian yang diberikan seseorang kepada hakim, petugas atau pejabat tertentu dengan tujuan yang diinginkan oleh kedua belah pihak, baik pemberi maupun penerima pemberian tersebut.

\footnotetext{
${ }^{22}$ Muhammad Abu Zahrah, al-Jarîmah wa al-'Uqûbah fî al-Fiqh al-Islâmiy, (Kairo: Maktabah alAngelo al-Mishriyah, tt.), 22.

23 Al-Mâwardiy, al-Ahkâm as-Sulthâniyyah, (Mesir: Maktabah Musthafa al-Bab al-Halabiy, 1973), 219.
} 
Islam sangat melarang perbuatan suap, terlebih jika dilakukan oleh pejabat negara. Perilaku suap dipandang bertentangan dengan prinsip kejujuran, kredibilitas kerja, dan keadilan. Sebab, dengan adanya suap maka nilai-nilai keadilan akan terkikis oleh kepentingan dari pihak yang menyuap. $(42):^{24}$

Larangan risywah tercantum dalam al-Qur'an Surat al-Maidah

Mereka itu adalah orang-orang yang suka mendengar berita bohong, banyak memakan yang haram jika mereka (orang Yahudi) datang kepadamu (untuk meminta putusan), maka putuskanlah (perkara itu) di antara mereka, atau berpalinglah dari mereka; jika kamu berpaling dari mereka maka mereka tidak akan memberi mudharat kepadamu sedikitpun. Dan jika kamu memutuskan perkara mereka, maka putuskanlah (perkara itu) di antara mereka dengan adil, sesungguhnya Allah menyukai orang-orang yang adil.

Terdapat sebuah hadis yang menerangkan tentang pelarangan perbuatan risywah ini: ${ }^{25}$

Dari Abu Hurairah ra, ia berkata; Rasulullah saw melaknati penyuap dan yang disuap dalam masalah hukum. (Sunan At-Tirmižiy hadīís Nomor 1256)

Namun menurut al-Syaukaniy, ada beberapa bentuk risywah yang dibenarkan dengan alasan untuk memperjuangkan hak atau menolak kezaliman yang mengancam keselamatan diri seseorang. Ibn Taimiyyah menjelaskan tentang alasan suap yang dibenarkan, dalam Majmû' Fatâwânya mengutip sebuah hadis yang diriwayatkan oleh Imam Ahmad ibn Hanbal bahwa Rasulullah saw pernah memberikan sejumlah uang kepada orang yang selalu meminta-minta kepada beliau.

Hukum perbuatan risywah disepakati oleh para ulama adalah haram, khususnya risywah yang terdapat unsur membenarkan yang salah dan atau menyalahkan yang harusnya benar. Akan tetapi, para ulama menganggap halal sebuah bentuk suap yang dilakukan dalam rangka menuntut atau memperjuangkan hak yang harusnya diterima oleh pihak pemberi suap atau dalam rangka menolak kezaliman, kemudharatan, dan ketidakadilan yang dirasakan oleh pemberi suap.

Dalam kasus penyuapan, biasanya melibatkan tiga unsur utama, yaitu pemberi suap (al-râsyiy), penerima suap (al-murtasyiy), dan barang

\footnotetext{
${ }^{24}$ Departemen Agama, Al-Qur'an dan Terjemahnya, 152.

${ }^{25}$ HR. Sunan At-Tirmidziy Hadis No. 1256 (Lidwa Pustaka I Software)
} 
atau nilai yang diserah terimakan dalam kasus suap. Namun demikian, tidak menutup kemungkinan dalam suatu kasus suap juga melibatkan pihak keempat sebagai broker perantara antara pemberi dan penerima suap. Broker atau perantara ini disebut al-râsyiy.

Perspektif hukum pidana Islam, suatu tindakan dinamakan risywah (suap) jika memenuhi unsur-unsur berikut:

a. Adanya athiyyah (pemberian)

b. Ada niat istimâlah (menarik simpati orang lain)

c. Bertujuan:

(1) Ibthâl al-haq (membatalkan yang haq)

(2) Ihqâq al-bâthil (merealisasikan kebathilan)

(3) al-mahsûbiyyah bi ghair al-haq (mencari keberpihakan yang tidak dibenarkan)

(4) al-hushûl alâ al-manâfi' (mendapatkan kepentingan yang bukan menjadi haknya)

(5) al-hukm lah (memenangkan perkaranya)

\section{Penyertaan Tindak Pidana Suap (Isytirâk fî Jarîmah al-Risywah)}

Turut serta berbuat jarîmah dalam bahasa Arab disebut dengan alisytirâk fî al-jarîmah berarti perbuatan yang dilakukan dua orang atau lebih, baik secara langsung atau tidak langsung yang menyebabkan suatu jarîmah. ${ }^{26}$ Pengertian turut serta berbuat jarîmah sesungguhnya berbeda dengan berserikat dalam melakukan tindak pidana. Turut serta berbuat jarîmah dapat terjadi tanpa menghendaki ataupun bersama-sama menghendaki hasil dari perbuatan tindak pidana atau perbuatan yang dimaksud. Sedangkan berserikat dalam jarîmah adalah sama-sama melakukan dan menghendaki, demikian juga hasil dari perbuatan pidana juga sama-sama dikehendaki. ${ }^{27}$ Dalam turut serta terlihat adanya pelaku utama dan adanya pembantu, sedangkan pada berserikat keduanya merupakan pelaku utama.

Adapun dasar hukum turut serta dan berserikat dalam tindak pidana adalah hadis maushûl riwayat Daruqutni: ${ }^{28}$

\footnotetext{
${ }^{26}$ Muhammad Abu Zahrah, al-Jarîmah Wa al-Uqûbah..., 292.

${ }^{27}$ Haliman, Hukum Pidana Islam menurut Ajaran Ahli Sunnah wal Jamaah, (Jakarta: Bulan Bintang, 1967), 225.

${ }^{28}$ Makhrus Munajat, Hukum Pidana Islam di Indonesia, (Yogyakarta: Bidang Akademik UIN Sunan Kalijaga, 2008), 63.
} 
"Dari Ibn Umar ra bahwa Nabi saw bersabda: "Apabila ada seseorang memegang orang lain, kemudian ada orang lain membunuhnya, maka pembunuh itu harus dibunuh dan pemegang itu ditahan."

Suatu jarîmah adakalanya diperbuat oleh seorang diri atau adakalanya oleh beberapa orang. Apabila diperbuat oleh beberapa orang, maka bentuk-bentuk kerjasama antara mereka tidak lebih dari empat: ${ }^{29}$

a. Pembuat melakukan jarîmah bersama-sama orang lain (memberikan bagiannya dalam melaksanakan jarîmah). Artinya secara kebetulan melakukan bersama-sama.

b. Pembuat mengadakan persepakatan dengan orang lain untuk melaksanakan jarîmah.

c. Pembuat menghasut (menyuruh) orang lain untuk memperbuat jarîmah.

d. Memberi bantuan atau kesempatan untuk dilakukannya jarîmah dengan berbagai cara, tanpa turut berbuat.

Turut serta melakukan jarîmah itu ada dua macam:

a. Turut berbuat jarîmah langsung

Terjadi apabila orang-orang yang melakukan jarîmah dengan nyata lebih dari satu orang. Pengertian melakukan jarîmah dengan nyata disini adalah bahwa setiap orang yang turut serta itu masing-masing itu mengambil bagian secara langsung, walaupun tidak sampai selesai. ${ }^{30}$

Dalam hubungannya dengan turut berbuat jarîmah, para fuqaha mengenal dua macam turut berbuat jarîmah langsung yaitu at-tawâfuq dan al-tamallu'.

(1) At-tawâfuq adalah beberapa orang yang melakukan suatu kejahatan secara bersama tanpa kesepakatan sebelumnya. Jadi, kejahatan itu terjadi karena adanya pengaruh psikologis dan pemikiran yang datang secara tiba-tiba. Seperti kejahatan yang terjadi ketika sedang berlangsungnya demonstrasi, yang tanpa perencanaan sebelumnya untuk melakukan suatu kejahatan. Dalam kasus ini, para pelaku kejahatan hanya bertanggung jawab atas perbuatannya masingmasing.

(2) Al-tamallu’ adalah kejahatan yang dilakukan oleh beberapa orang secara bersama dan terencana. Misalnya pembunuhan atas

\footnotetext{
${ }^{29}$ Ahmad Hanafi, Asas-asas Hukum Pidana Islam, (Jakarta: Bulan Bintang, 1976), 154.

${ }^{30}$ Ahmad Wardi Muslich, Pengantar dan Asas Hukum Pidana Islam, (Jakarta: Sinar Grafika, 2004), 67-68.
} 
seseorang oleh sekelompok orang secara terencana: ada yang mengikatnya, ada yang memukulnya, ada yang menembaknya. Mereka semua bertanggung jawab atas kematian korban. ${ }^{31}$

b. Turut berbuat jarîmah tidak langsung

Turut berbuat tidak langsung ialah setiap orang yang mengadakan perjanjian dengan orang lain untuk melakukan suatu perbuatan yang dapat dihukum, atau menyuruh (menghasut) orang lain atau memberi bantuan dalam perbuatan tersebut dengan disertai kesengajaan dalam persepakatan dan menyuruh serta memberi bantuan. ${ }^{32}$

Turut berbuat jarîmah tidak langsung yaitu seperti orang yang menyuruh orang lain untuk membunuh orang ketiga. Dalam kasus ini, menurut para ulama di kalangan madzhab Maliki, Syafi'i, dan Ahmad, orang yang menyuruh itulah yang dianggap sebagai pelaku pembunuhan. Karena orang yang diruruh itu hanyalah alat yang digerakkan oleh si penyuruh. ${ }^{33}$ Adapun menurut Abu Hanifah, si penyuruh itu tidak dianggap sebagai pelaku langsung kecuali bila suruhannya itu sudah sampai pada tingkat paksaan. Dalam kasus suruhan yang tidak sampai pada tingkat paksaan yang disuruh itu bertanggung jawab atas kematian korban, sedangkan yang menyuruh dikenai sanksi ta'zîr. ${ }^{34}$

Turut berbuat tidak langsung terjadi dengan cara-cara sebagai berikut: ${ }^{35}$

\section{(1) Persepakatan}

Persepakatan bisa terjadi karena adanya saling pengertian dan kesamaan kehendak untuk melakukan suatu jarîmah. Kalau tidak ada persepakatan sebelumnya maka tidak terdapat turut berbuat. Meskipun ada persepakatan tetapi jarîmah yang terjadi bukan yang disepakati maka juga tidak ada turut berbuat. Dengan demikian untuk terjadinya turut berbuat dengan cara persepakatan, jarîmah yang terjadi harus merupakan akibat dari persepakatan itu.

(2) Suruhan dan hasutan

Menyuruh atau menghasut adalah membujuk orang lain untuk melakukan suatu jarîmah dan bujukan itu menjadi pendorong untuk dilakukannya jarîmah itu. Bujukan atau hasutan terhadap orang lain

\footnotetext{
${ }^{31}$ Al-Ramli, Nihâyah al-Muhtâj, (Mesir: al-Bab al-Halabi, tt.), 261.

${ }^{32}$ Haliman, Hukum Pidana Islam..., 227.

${ }^{33}$ Abu Ishaq al-Syirazy, Al-Muhadzdzab, (Mesir: Isa Al-Bab Al-Halabi, tt.), 189.

${ }^{34}$ Abdul Qadir 'Awdah, at-Tasyrî' al-Jinâ'iy al-Islâmiy, (Beirut: Dar al-Kitab al-Arabiy, tt.), 362.

${ }^{35}$ Ahmad Wardi Muslich, Pengantar dan Asas..., 71.
} 
untuk melakukan suatu jarîmah merupakan suatu maksiat yang sudah bisa dijatuhi hukuman.

Dalam tingkatan paling rendah dorongan bisa berupa memberi semangat kepada orang lain untuk melakukan jarîmah. Paksaan merupakan tingkatan yang lebih tinggi lagi. Paksaan ini terjadi apabila orang yang mengeluarkan perintah atau bujukan itu mempunyai kekuasaan atas orang yang diperintahnya, seperti orang tua terhadap anaknya atau atasan kepada bawahannya.

(3) Memberi bantuan

Orang yang memberikan bantuan kepada orang lain dalam melaksanakan suatu jarîmah dianggap sebagai kawan berbuat tidak langsung, meskipun tidak ada persepakatan sebelumnya. Seperti mengamati jalan untuk memudahkan proses pencurian bagi orang lain.

\section{Unsur-unsur Penyertaan dalam Tindak Pidana}

Dalam terminologi fikih jinâyah, dikenal istilah arkân al-jarîmah (rukun-rukun jarimah). Rukun tersebut terdiri dari al-rukn al-syar'iy (ada tidaknya nash), al-rukn al-mâddiy (unsur materiil) dan al-rukn al-adabiy (unsur moril). ${ }^{36}$

Yang dimaksud dengan rukun syar'i adalah ada atau tidaknya nash yang melarang suatu jarîmah. Sedangkan dari segi materiil, unsur-unsur yang harus ada dalam delik penyertaan dalam hukum pidana Islam secara umum ada dua, yaitu:

a. pelakunya lebih dari satu,

b. semua pelaku melakukan perbuatan yang mengakibatkan terjadinya suatu jarîmah tertentu.

Unsur moril berbicara mengenai niat/maksud para pelaku dalam melakukan suatu tindak pidana. ${ }^{37}$

\section{Hukuman bagi Pelaku Jarîmah Risywah}

Hukuman dalam hukum pidana Islam bertujuan untuk memelihara dan menciptakan kemaslahatan manusia dan menjaga mereka dari hal-hal yang mafsadah, karena Islam itu sebagai rahmat li al-âlamîn, untuk memberi petunjuk dan pelajaran kepada manusia. ${ }^{38}$

\footnotetext{
${ }^{36}$ Kamil Muhammad Husain Hamid,"Ahkâm al-lsytirâk Fî al-Jarîmah Fî al-Fiqh al Islâmiy (Dirâsah Muqâranah Ma'a al-Qânûn al-Wadh'iy", Skripsi, (Palestina: Jami'ah an-Najah al-Wathaniyah, 2010), 58.

${ }^{37}$ Ahmad Hanafi, Asas-Asas Hukum Pidana..., 59.

${ }^{38}$ A. Djazuli, Fiqh Jinayah, 25.
} 
Dalam hukum pidana Islam memang tidak ada nash yang secara khusus mencatat dengan jelas sanksi dari perbuatan korupsi. Islam mengkaitkan perbuatan korupsi ini diidentifikasi dengan beragam bentuknya seperti ghulûl (penggelapan), risywah (suap), ghasab (mengambil hak secara paksa), khiyânah (pengkhianatan), dan sariqah (pencurian). Ketentuan perbuatan-perbuatan tersebut, kecuali sariqah, tidaklah termasuk dalam hukuman hudûd, sehingga hukuman akan diganti dengan hukuman ta'zîr. Jenis-jenis hukum ta'zîr yang dapat diterapkan bagi pelaku korupsi dalam bentuk suap adalah; penjara, pukulan yang tidak menyebabkan luka, menampar, dipermalukan (dengan kata-kata atau dengan mencukur rambutnya), diasingkan, dan hukuman cambuk di bawah empat puluh kali. Khusus untuk hukuman penjara, Qalyûbiy berpendapat bahwa boleh menerapkan hukuman penjara terhadap pelaku maksiat yang banyak memudharatkan orang lain dengan penjara sampai mati (seumur hidup).

Sanksi risywah bagi para ulama memberikan pendapat yang berlainan satu sama lain. Abdullah Muhsin al-Thariqi mengemukakan bahwa sanksi hukum pelaku risywah (suap) tidak dijelaskan secara jelas oleh al-Qur'an dan hadis, mengingat bahwa sanksi risywah masuk dalam kategori sanksi ta'zîr yang kekuasaannya berada di tangan hakim. Untuk menentukan jenis sanksi yang sesuai dengan kaidah-kaidah hukum Islam dan sejalan dengan prinsip untuk memelihara stabilitas hidup bermasyarakat sehingga berat dan ringannya sanksi hukum harus disesuaikan dengan jenis tindak pidana yang dilakukan.

Jarîmah ta'zîr adalah jarîmah yang diancam dengan hukuman ta'zîr. Secara ringkas dapat dikatakan bahwa hukuman ta'zîr itu adalah hukuman yang belum ditetapkan oleh syara', melainkan diserahkan kepada ulîl amri baik penentuannya maupun pelaksanaannya.

Pada jarîmah ta'zîr, al-Qur'an dan hadis tidak menerapkan secara terperinci, baik dari segi bentuk jarîmah maupun hukumannya. ${ }^{39}$ Dasar hukum disyariatkannya sanksi bagi pelaku jarîmah ta'zîr adalah at-ta'zîr yadûru ma'a al-mashlahah artinya, hukum ta'zîr didasarkan pada pertimbangan kemashlahatan dengan tetap mengacu kepada prinsip keadilan dalam masyarakat. ${ }^{40}$

\footnotetext{
${ }^{39}$ Jaih Mubarok, Kaidah-Kaidah Figh Jinayah, (Bandung: Pustaka Bani Quraisy, 2004), 47.

${ }^{40}$ Makhrus Munajat, Reaktualisasi Pemikiran Hukum Pidana Islam, (Yogyakarta: Cakrawala, 2006), 14.
} 
Menurut Syarbini al-Khatib, bahwa ayat al-Qur'an yang dijadikan landasan adanya jarîmah ta'zîr adalah QS. al-Fath ayat 8-9:41

Sesungguhnya Kami mengutus kamu sebagai saksi, pembawa berita gembira dan pemberi peringatan, supaya kamu sekalian beriman kepada Allah dan Rasul-Nya, menguatkan (agama)Nya, membesarkan-Nya. dan bertasbih kepada-Nya di waktu pagi dan petang.

Konsekuensi bagi hakim yang lalai dalam menjalankan tugasnya dan bertindak curang dalam memberikan suatu putusan maka ancaman hukuman berat baginya tidak hanya di dunia melainkan juga di akhirat dan hukuman bagi pelaku suap di dunia ditentukan oleh negara.

Sedangkan dalam kasus percobaan penyuapan sendiri, para fuqâha tidak membahas secara intensif. Setidaknya ada dua faktor penyebab: ${ }^{42}$ Pertama, percobaan melakukan jarîmah (kejahatan) tidak dikenai hukuman had atau qishâsh, melainkan dengan hukuman ta'zîr di mana hukuman ini diserahkan pada negara. Kedua, dengan adanya aturan yang mencakup tentang hukuman jarîmah ta'zîr, maka tidak perlu diadakan aturan-aturan khusus yang mengatur tentang percobaan. Sebab hukuman ta'zîr dijatuhkan atas perbuatan maksiat selama tidak dijatuhi hukuman had atau qishâsh. Atau dengan kata lain percobaan telah dipandang sebagai maksiat yang tidak selesai maka bagi pelakunya dikenai hukuman ta'zîr.

Dalam perspektif hukum pidana Islam, para fuqaha lebih membahas tentang orang yang turut berbuat secara langsung dalam kasus pidana. Karena menurut syariat Islam, hukuman yang telah ditentukan hanya dijatuhkan atas orang yang turut berbuat secara langsung, bukan untuk orang yang terlibat secara tidak langsung. Pandangan ini dikemukakan oleh Imam Abu Hanifah. ${ }_{-23}^{3}$

Berbagai peraturan perundang-undangan yang dibuat untuk menanggulangi dan memberantas korupsi di negeri ini sudah jauh lebih baik dan ideal bila dibandingkan dengan konsep yang masih merupakan doktrin hukum yang terdapat dalam kitab-kitab fikih. Berbagai peraturan perundang-undangan merupakan bentuk konkret dari konsep ta'zîr yang ditawarkan oleh fikih jinayâh, yaitu sebuah sanksi hukum yang tidak dijelaskan secara tegas mengenai jenis dan teknis serta tata cara pelaksanaannya oleh al-Qur'an dan hadis-hadis Rasulullah, melainkan diserahkan kepada pemerintah dan hakim setempat.

\footnotetext{
${ }^{41}$ Departemen Agama, Al-Qur'an dan Terjemahnya, 738.

${ }^{42}$ Ahmad Hanafi, Asas-Asas Hukum..., 118.

${ }^{43}$ Ibid., 137.
} 
Di dalam syariah Islam terdapat ketentuan bahwa orang yang melakukan pelanggaran tindak pidana itu mendapatkan hukuman berupa had ataupun ta'zîr. Had adalah hukuman yang sudah Allah jelaskan dan tentukan dalam Alquran ataupun hadis bagi para pelanggarnya, misalnya, hukum zina bagi orang yang sudah pernah menikah adalah dirajam, hukum potong tangan bagi para pencuri. Sedangkan ta'zîr adalah hukuman yang dijatuhkan kepada para pelanggar hukum tindak pidana, akan tetapi belum dijelaskan oleh Alquran maupun hadis. Misalnya, menyewakan rahim seorang ibu, mengkonsumsi narkoba, dan lain-lain.

Korupsi dalam bentuk suap merupakan bentuk tindak pidana yang belum ditentukan hukumannya oleh syariat, bentuk pidana seperti ini dalam Islam dinamakan jarîmah ta'zîr. Adapun hukuman dari pelanggar jarîmah itu sangat variatif, sesuai dengan kadar tindak kejahatan dan keputusan hakim, mulai dari yang paling ringan sampai dengan yang paling berat.

Hukuman-hukuman ta'zîr ialah:

\section{a. Hukuman mati}

Pada dasarnya hukuman ta'zîr dalam syariah hanya terbatas pada ta'dîb (pengajaran), dan tidak sampai membinasakan. Oleh karena itu sebenarnya tidak boleh ada unsur penghilangan fungsi anggota badan ataupun penghilangan nyawa.

Akan tetapi para fukaha membuat pengecualian dari aturan umum tersebut, yaitu dibolehkanya dijatuhkannya hukuman mati. Dijatuhkannya hukuman ini karena tidak ada cara lain untuk memberantas tindak pidana tersebut, seperti mata-mata, pembuat fitnah, residivist yang berbahaya. Jikalau di negara ini terdapat banyak kasus korupsi dan tidak ada hukuman yang membuat pelaku jera, maka hukuman ini bisa dilaksanakan demi terlaksananya negara yang sejahtera. b. Hukuman kurungan

Ada dua macam hukuman kurungan dalam syariah Islam, yaitu hukuman kurungan terbatas dan hukuman kurungan tidak terbatas (dilihat dari segi lamanya waktu).

(1) Hukuman kurungan terbatas

Batas minimal bagi hukuman ini ialah satu hari, sedangkan batas maksimalnya tidak ada kesepakatan dari para ulama. Penetapan hukuman ini disyaratkan bahwa hukuman tersebut menjadikan perbaikan pada pelaku. Kalau hukuman ini tidak sesuai dengan 
harapan awal, maka hukuman lain bisa dijatuhkan pada waktu masih dalam kurungan.

Ada beberapa perbedaan antara hukum positif dengan hukum Islam mengenai hukuman pokok dalam kasus pidana. Dalam hukum positif hukuman kurungan merupakan hukuman utama, sedangkan dalam hukum Islam dalam menentukan hukuman lebih subjektif, tergantung pada berat ringannya kasus.

(2) Hukuman kurungan tidak terbatas

Hukuman ini tidak ada batasan waktunya, jika pelaku sudah jera dan bertaubat maka ketika itu dia sudah bisa keluar dari kurungan, jika tidak menjadi baik ataupun bertaubat maka bisa selamanya dipenjara. Orang-orang tersebut adalah pelaku tindak pidana berat, seperti perampok, pembunuhan dan penganiayaan. ${ }^{44}$

Dalam sebuah kitab fikih menjelaskan bahwa pelaku korupsi terjerat beberapa hukum. Yang pertama adalah hukuman mati, karena korupsi tersebut sudah menjadikan suatu negara atau instansi. Hukuman kedua bagi koruptor atau pelaku korupsi adalah diambil hartanya, hal ini bertujuan untuk mengembalikan harta negara yang sudah mereka makan. ${ }^{45}$

\section{Analisis Hukum Pidana Islam tentang Sanksi Tindak Pidana Turut Serta sebagai Perantara Suap}

Hukum pidana Islam adalah salah satu hukum islam yang mengatur tentang perbuatan yang dilarang oleh syara' membahayakan bagi jiwa, harta, dan lainnya. ${ }^{46}$

Penegakan hukum pidana Islam sangat penting sebagai amanat Allah swt. Selain itu terdapat tujuan dalam hukum pidana Islam, diantaranya: menjamin keamanan lima pokok kebutuhan hidup yang primer (dharûriyyât), atau disebut dengan istilah al-maqâshîd al-khamsah, meliputi: agama, jiwa, akal dan pikiran, keturunan, dan hak milik. Selanjutnya kebutuhan sekunder atau disebut (hâjiyyât), dan yang terakhir adalah kebutuhan tersier (tahsîniyyât), yaitu menjadikan hal-hal yang dapat menghiasi kehidupan sosial dan menjadikan manusia mampu berbuat dan mengatur urusan hidup lebih baik. ${ }^{47}$

\footnotetext{
${ }^{44}$ Ibid., 299.

${ }^{45}$ Wahbah al-Zuhailiy, al-Figh al-lslâmiy Wa Adillatuhu, 201.

${ }^{46}$ Abdul Qadir Awdah, at-Tasyrî̀ al-jinâ'iy al-Islâmiy, 67.

${ }^{47}$ Topo Santoso, Membumikan Hukum Pidana Islam, 19.
} 
Contoh tindak pidana turut serta sebagai perantara suap, adalah tindak pidana turut serta sebagai perantara suap terhadap hakim yaitu tindak pidana berupa ikut serta dalam menerima hadiah atau janji bersama-sama hakim, diketahui atau patut diduga bahwa hadiah atau janji tersebut diberikan untuk mempengaruhi putusan perkara yang diserahkan kepadanya untuk diadili.

Korupsi dalam bentuk suap termasuk extra ordinary crime (kejahatan luar biasa) sehingga pemberantasannya harus dilakukan dengan cara yang luar biasa; mengingat dampak dari Tindak pidana korupsi selama ini, selain merugikan keuangan negara juga menghambat pertumbuhan dan kelangsungan pembangunan nasional yang menuntut efisiensi tinggi; dan untuk merespon akibat yang ditimbulkan, maka perlu tindakan tegas bagi para pelakunya.

Islam sangat melarang perbuatan suap, terlebih jika dilakukan oleh pejabat negara. Perilaku suap dipandang bertentangan dengan prinsip kejujuran, kredibilitas kerja, dan keadilan. Sebab, dengan adanya suap maka nilai-nilai keadilan akan terkikis oleh kepentingan dari pihak yang menyuap.

Terdapat sebuah hadis yang menerangkan tentang pelarangan perbuatan risywah ini: ${ }^{48}$

Dari Abū Hurairah ra, ia berkata; Rasulullah saw melaknati penyuap dan yang disuap dalam masalah hukum. (Sunan At-Tirmiżiy hadīś Nomor 1256)

Namun menurut al-Syaukani, ada beberapa bentuk risywah yang dibenarkan dengan alasan untuk memperjuangkan hak atau menolak kezaliman yang mengancam keselamatan diri seseorang. Ibn Taimiyyah menjelaskan tentang alasan suap yang dibenarkan, dalam Majmu' Fatâwânya mengutip sebuah hadis yang diriwayatkan oleh Imam Ahmad bin Hanbal bahwa Rasulullah saw pernah memberikan sejumlah uang kepada orang yang selalu meminta-minta kepada beliau.

Hukum perbuatan risywah disepakati oleh para ulama adalah haram, khususnya risywah yang terdapat unsur membenarkan yang salah dan atau menyalahkan yang harusnya benar. Akan tetapi, para ulama menganggap halal sebuah bentuk suap yang dilakukan dalam rangka menuntut atau memperjuangkan hak yang harusnya diterima oleh pihak

${ }^{48}$ HR. Sunan At-Tirmidziy Hadis No. 1256 (Lidwa Pustaka Software). 
pemberi suap atau dalam rangka menolak kezaliman, kemudharatan, dan ketidakadilan yang dirasakan oleh pemberi suap.

Menurut analisis penulis dari sumber-sumber data yang telah terkumpulkan dapat diketahui bahwasanya perkara tindak pidana turut serta sebagai perantara suap dalam hukum pidana Islam dapat dikatakan isytirâk fi jarîmah al-risywah dengan unsur kesengajaan, terhadap pelaku dijerat hukuman ta'zîr sebagaimana ditetapkan pada jarîmah risywah.

Menurut, analisis penulis hukuman jarîmah ta'zîr lebih tepat diterapkan pada pelaku tindak pidana turut serta sebagai perantara suap. Penulis menggolongkan jarîmah turut serta dalam melakukan risywah ke dalam turut berbuat jarîmah risywah langsung, bersama-sama, dan terencana (al-tamallu')

Hukuman ta'zîr adalah hukuman yang diberikan oleh hakim, maka dalam perkara ini hakim memiliki wewenang dalam menyelesaikan dan memutus perkara berdasarkan Undang Undang yang berlaku dan peraturan-peraturan yang berlaku

Hukum pidana Islam sebagai bagian dari hukum Islam itu sendiri, menerapkan hukuman dengan tujuan menciptakan sebuah ketentraman individu dan masyarakat serta mendidik dan mencegah perbuatanperbuatan yang melanggar aturan dan undang undang yang ditetapkan tentunya memperbaiki perilaku moral yang tidak baik di masyarakat.

\section{Simpulan}

Penyertaan (deelneming) dalam hukum positif yaitu ada dua orang atau lebih yang melakukan suatu tindak pidana atau dengan perkataan ada dua orang atau lebih mengambil bagian untuk mewujudkan suatu tindak pidana dapat disebutkan bahwa seseorang tersebut turut serta dalam hubungannya dengan orang lain (diatur dalam pasal 55 dan 56 KUHP).

Hukuman bagi pelaku korupsi dalam perundangan-undangan Indonesia telah diatur secara jelas dan lengkap, yakni dalam UndangUndang Nomor 31 Tahun 1999 jo Undang-Undang Nomor 20 Tahun 2001 tentang Pemberantasan Tindak Pidana Korupsi. Ancaman hukuman bagi pelakunya, baik itu suap, gratifikasi, dan lain-lain, akan dikenakan hukuman penjara dan/atau denda. Bahkan dalam ketentuan khususnya, apabila korupsi dilakukan dengan mengakibatkan bahaya bagi negara, seperti terjadi bencana nasional atau pada saat negara dalam keadaan krisis ekonomi, maka dapat diancam hukuman mati. Tujuan penerapan 
hukuman dalam hukum positif yaitu menciptakan kepastian, keadilan, dan kemanfaatan hukum di Indonesia.

Tujuan pemberian hukuman dalam hukum pidana Islam yaitu merealisasikan kemaslahatan umat dan sekaligus menegakkan sebuah keadilan. Dalam jarîmah ta'zîr, hakim dapat memilih bentuk hukuman yang tepat bagi pelaku kejahatan, disesuaikan dengan unsur formil dan materiil dalam tindak pidana.

Hukum Pidana Islam menggolongkan turut serta dalam tindak pidana suap ke dalam jarîmah langsung, bersama-sama, dan terencana (altamallu') dalam melakukan risywah. Sehingga hukum pidana Islam memberikan hukuman ta'zîr bagi pelaku tindak pidana turut serta (isytirâk fi al-jarîmah) sebagai perantara suap (risywah). Karena tidak ada nash pun dalam al-Qur'an dan hadis yang memberikan petunjuk terkait sanksi bagi pelaku yang turut serta dalam jarîmah risywah. Sehingga hakimlah yang menentukan hukumannya dengan memperhatikan nilai-nilai keadilan yang berlaku secara formil dalam peraturan perundangan dan materiil dalam masyarakat.

\section{Daftar Rujukan}

Awdah, Abdul Qadir. at-Tasyrî’ al-Jinâ’iy al-Islâmiy. Beirut: Dar al-Kitab al-Araby, tt.

Chadawi, Adami. Pelajaran Hukum Pidana Bagian I. Jakarta: Raja Grafindo Persada, 2002.

Departemen Agama. Al-Qur'an dan Terjemahnya. Surabaya: CV. Karya Utama, 2000.

Djazuli, A. Fiqh Jinayah. Jakarta: Raja Grafindo Persada, 2000.

Effendi, Erdianto. Hukum Pidana Indonesia. Bandung: Refika Aditama, 2011.

Firdaus, Edwin. "Jaksa KPK banding vonis Susi tur Andayani", tribunnews paper. 23 Juni 2014.

Haliman. Hukum Pidana Islam menurut Ajaran Ahli Sunnah wal Jamaah. Jakarta: Bulan Bintang, 1967.

Hanafi, Ahmad. Asas-asas Hukum Pidana Islam. Jakarta: Bulan Bintang, 1976.

Hartanti, Evi. Tindak Pidana Korupsi. Jakarta, Sinar Grafika, 2012.

HR. Sunan At-Tirmidziy Hadis Nomor 1256. Lidwa Pustaka i Software. Ilyas, Amir. Asas-Asas Hukum Pidana. Yogyakarta: Mahakarya Rangkang Offset, 2012. 
Kamil Muhammad Husain. "Ahkâm al-Isytirâk Fî al-Jarîmah Fî al-Fiqh al Islâmiy (Dirâsah Muqâranah Ma'a al-Qânûn al-Wadh’iy)”. Skripsi. Palestina: Jami'ah an-Najah al-Wathaniyah, 2010.

Kartanegara, Satochid. Hukum Pidana Kumpulan Kuliah bagian satu. (Balai Lektur Mahasiswa).

Komisi Pemberantasan Korupsi. Memahami untuk Membasmi (Buku Saku untuk Memahami Tindak Pidana Korupsi). Jakarta: KPK, 2006.

Al-Mâwardiy. al-Ahkâm aAs-Sulthâniyyah. Mesir: Maktabah Musthafa Al-Bab Al-Halabiy, 1973.

Mubarok, Jaih. Kaidah-Kaidah Fiqh Jinayah. Bandung: Pustaka Bani Quraisy, 2004.

Munajat, Makhrus. Hukum Pidana Islam di Indonesia. Yogyakarta: Bidang akademik UIN Sunan Kalijaga, 2008. Reaktualisasi Pemikiran Hukum Pidana Islam. Yogyakarta: Cakrawala, 2006.

Muslich, Ahmad Wardi. Pengantar dan Asas Hukum Pidana Islam. Jakarta: Sinar Grafika, 2004.

Ramli. Nihâyah al-Muhtâj. Mesir: al-Bab al-Halabiy, tt..

Salam, Moch. Faizal. Hukum Acara Pidana dalam Teori dan Praktek. Bandung: Mandar Maju, 2001.

Santoso, Topo. Membumikan Hukum Pidana Islam. Jakarta: Gema Insani Press, 2003.

Sekretariat Jenderal MPR RI, Undang Undang Dasar 1945 dalam Satu Naskah. Jakarta: Sekjen MPR RI, 2013.

Sjadzali, Munawir. Islam dan Tata Negara. Jakarta: Universitas Indonesia, 1993.

Syamsuddin, Azis. Tindak Pidana Khusus. Jakarta: Sinar Grafika, 2011.

Al-Syirâziy, Abu Ishaq. aAl-Muhadzdzab. Mesir: Isa Al-Bab Al-Halabiy, tt.

Taimiyah, Ibn. Siyasah Syar'iyah; Etika Politik Islam. Surabaya: Risalah Gusti, 1999.

Tim Grahamedia Press, KUHP \& KUHAP. Surabaya: Grahamedia Press, 2012.

UU Nomor 31 Tahun 1999 jo UU Nomor 20 Tahun 2001 tentang Pemberantasan Tindak Pidana Korupsi. 
Zahrah, Muhammad Abu. al-Jarîmah wa al-'Uqûbah fî al-Fiqh al-Islâmiy. Kairo: Maktabah al-Angelo al-Mishriyah, tt.

Al-Zuhailiy, Wahbah. al-Fiqh al-Islâmiy wa Adillatuhu. Damaskus: Dar al-Fikr, 2007. 